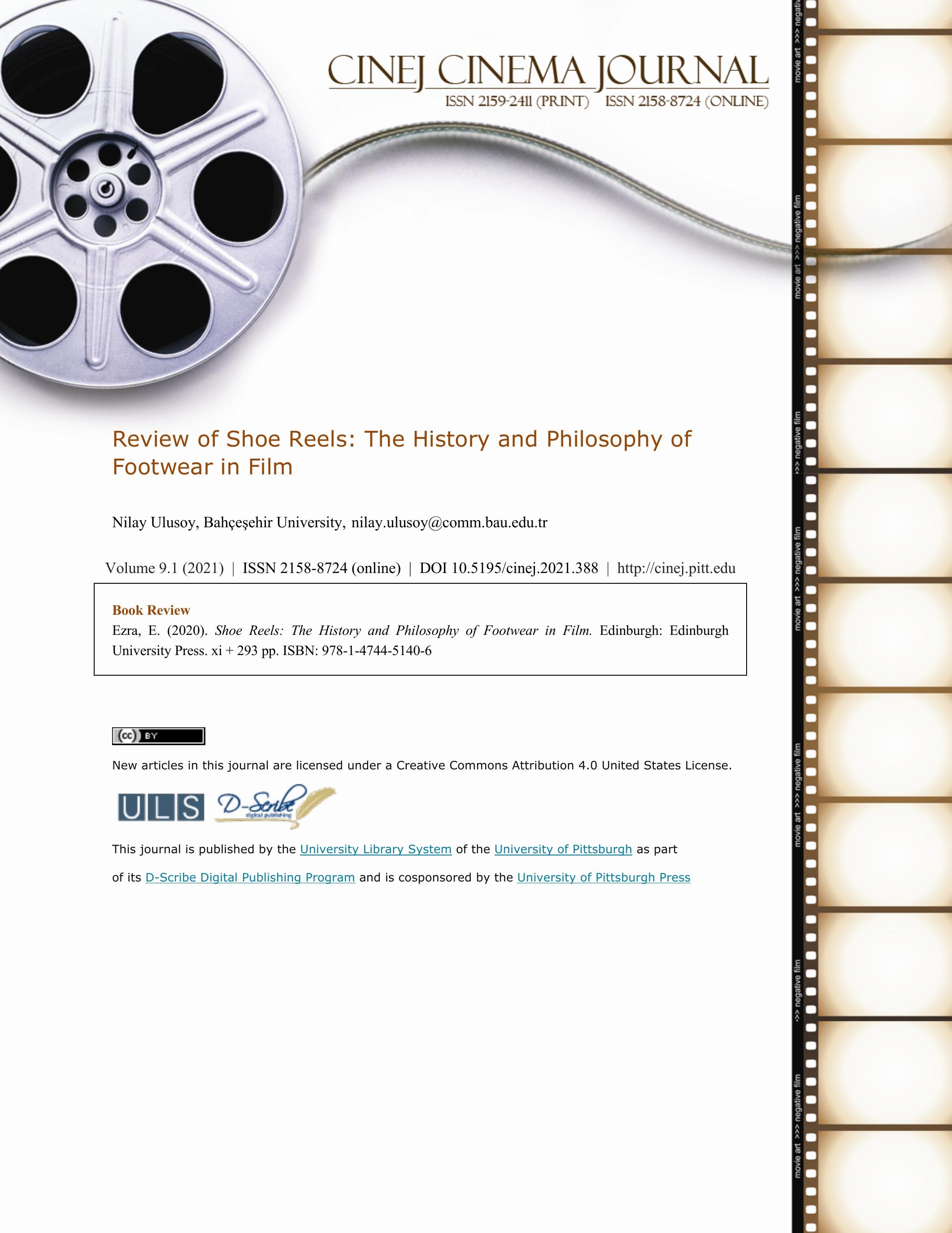




\section{Shoe Reels: The History and Philosophy of Footwear in Film Nilay Ulusoy}

While "Shoe Reels: The History and Philosophy of Footwear in Film" edited by Elizabeth

Ezra and Catherine Wheatley rewrites the history of cinema, it comes to the fore as an important sourcebook which tells how significant costumes and in particular shoes are in the narration of films. As Ezra and Wheatley indicate in their foreword, shoes can never be dealt with as mere accessories. Homo Sapiens' standing on two feet in its evolutionary process is an extremely important stage. The existence or lack of shoes, which emerge as important clothes in the continuation of this stage in terms of humans' protecting themselves in nature, creates numerous important meanings in our cultural world. Shoes, which can be a symbol of constraint as much as freedom and leisure as much as work, represent both physical and social mobility and reflect the contrasts in life. The old dingy shoes of laborers in Van Gogh's "Shoes" series bring the "breadlabor" relationship to the mind. However, shoes as one of the primary accessories which can explain Karl Marx's concept of meta fetishism in the most specific manner in capitalist societies as well. One of the mediums which best makes use of this passion for shoes is cinema. "Shoe Reels" embodies 20 articles about many famous shoes which have an important place in the narration of films since the beginning of cinema and almost become the hero of the films. As we take a look at the history of cinema with "Shoe Reels," we see that shoes are not merely accessories 
which complement outfits and that they are an important narrative element which shapes the form of films.

The first articles in Shoe Reels are about silent films. The book begins with Margaret C. Flinn's clumsy and awkward middle-class characters of Max Linder who wander aimlessly in the city and experience difficulties with modern city life and the film titled Les Escarpins de Max ( Max Linder, 1913).' Flinn states in her article that the element of humor which emerges with the misuse of articles in his rich life by Max Linder, who is one of the most important stars of silent cinema, is actually a class failure. Malgorzata Bugaş continues the early period cinema adventure of shoes with the film Amor Pedestre (Marcel Fabre, 1914) which introduces cinema as a popular form of entertainment of Marcel Fabre with art and the movement of futurism in "Shoe Reels." Following this interesting article which indicates that details about the characters played in silent cinema such as gender, age, social class, occupation, etc. are reflected with the close-up shots of shoes, Pamela Hutchinson talks about the passion of Lois Weber who is one of the first female directors of early cinema towards shoes in her films. We see that shoes are one of the best contributors to reflecting social hierarchy in stories which deal with the injustices experienced by working-class women. At the end of the 1930's in which sound and color totally transformed cinematic narration, shoes continue to take the leading roles in cinemascope films as well. In The 
Wizard of $\mathrm{Oz}$ (Victor Fleming, 1939) the studio's coloring of Dorothy's glass shoes ruby red appears as an important detail about how the color changes the stories of films. After the adventure of the ruby red shoes, Elizabeth Ezra identifies the fairytale of Cinderella, who finds her prince charming with the help of her glass shoes, with a more contemporary fairytale which is Sex and the City (HBO, 1998-2004) and Carrie Bradshaw's story in her article. Taking Keith Lodwick's article about the adventure of Dorothy's magic ruby shoes extends to the year 2012 and the Victoria and Albert Museum in London as a starting point, we can say that the stories about the ruby shoes are as exciting as Dorothy's own adventure. Ian Christie contributes to the book with his article on famous red shoes of the history of cinema. Christie associates the ruby shoes of Dorothy who wants to return to her home in Kansas with the shoes in Hans Christian Andersen's fairytale which turn red because of dancing. Christie, who associates the red shoes with the film The Red Shoes (Michael Powell, 1948) talks about how these famous red shoes carry transformative meanings in the lives of female characters who wear them. Dorothy and Victoria appear as characters who are able to go after their dreams with the help of their shoes.

Kelli Fuery deals with the film Sullivans Travel (Preston Sturgess, 1941) with the assumption that life can be viewed through two shoes and two different perspectives. The film, which ties the character Sully (Preston Sturgess) who is a famous actor with the two separate worlds of two different shoes emerges as the film adaptation of the expression "walking in 
another's shoes." Ana Salzberg explains to the reader that the steps Marilyn Monroe climbs with her translucent platform heels in another Hollywood classic How to Marry a Millionaire (Jean Negulesco, 1953) are actually a metaphor which carries the character Pola she played towards marrying a rich man. After Salzberg's 'How to Marry a Millionaire' which she defines as a Cinderella-gold digger narrative, the book continues with an article which talks about how the fairytale characters who make shoes enthusiastically and with pleasure in the animations adapted from the fairytales produced in Hollywood starting with the 1930's give the viewers an economic message. Christopher Holliday in his analysis of the animations in which some elves work in harmony and enthusiasm together explains how the slippers and shoes of 'human' cartoon characters whose faces are not seen in line with the developments which took place in $20^{\text {th }}$ century American history which introduce them to the viewers have gone under a transformation. It is not a coincidence that the Afro-American maids with patched socks and slippers were replaced with mothers with red high-heeled shoes starting with the 1960's.

"Shoe Reels" also deals with the life story about the friendship of fashion and cinema analyzed by Eugenia Paulicelli who gave place to the life story of Salvatore Ferragamo, who began working in the costume departments in Hollywood and became the most important representative of Italian style in the $20^{\text {th }}$ century with his designs. In the story which extends not only to 
Hollywood but to the Cinecitta Studios which were the heart of Italian cinema as well, Ferragamo's Rainbow sandals which he designed for Judy Garland in 1938 still influence the understanding of fashion in the present time.

In a second article about Cinecitta in which Robert A. Rushing analyzes the 'swords and sandals' films of the 1950's which were Italian-American coproductions dealt with the element of masculinity through the sandals worn by the characters in this subgenre which consists of cheap adaptations of mythological stories. In the article which also indicates the similarity between this subgenre of the 1950's with the film 300 (Zack Snyder, 2007) it is suggested that the 'incomplete' masculinity of the young make characters is symbolized with their naked feet. After Rushing's article, in which he states that even invincible mythological characters' process of proving themselves as men is depressive and open to anxiety, Louise Wallanberg analyzes three 'bromance' stories from Hollywood in which she touches upon the concept of hyper-masculinity. In Wallenberg's article which deals with macho film characters in terms of queer and feminist theories, it is indicated that masculinity produced through William Holden's cowboy boots and naked upper half of his body in the film Picnic (Joshua Logan, 1957) is actually visualized not only with the purpose of female gaze but also for the male viewers to imitate and desire. It is mentioned how the homosocial bonding between the characters idealized in a similar manner in the film The Lives of a Bengal Lancer (Henry Hathaway, 1935) is glorified with grand uniforms 
and boots. Wallenberg who indicates that a similar relationship exists between the two characters in the film Midnight Cowboy (John Schlesinger, 1969) suggests that the homoerotic desire between Joe, who tries to work as a male prostitute with his cowboy costume (Jon Voight), and Buck (Dustin Hoffman) is explicitly presented without being hidden with the influence of the New Hollywood movement as well. In her article, Lucy Bolton focuses on the shoes of Tippi Hedren in Alfred Hitchcock's 1964 dated film Marnie which facilitates the moods of the frigid and kleptomaniac characters she portrays. In the article which talks about how childhood trauma is influential in the wobbly and unbalanced walk of Marnie in her high-heeled stilettos who was entrapped by her control-freak husband Mark (Sean Connery), the outfits and accessories designed by Edith Head are dealt with dramatically as significant objects in the development of the character.

Rachael Langford in her article in "Shoe Reels" provides a break to an analysis of films focused on Europe and Hollywood and does a post-colonial reading on African cinema. The article discusses what rejecting to wear shoes and walking barefoot following a period in which the colonial point of view shaped the African body as a controlled and improved imaginative subject means in the fictional works of African writers and directors. It is expressed that, in contrast to bare feet deemed as uncivilized, the closed shoes or boots of the colonialists are a symbol of 
authority. Tyler Parks talks about how the clicks of shoes which overlap with the film music in the opening scene of one of the most known directors of Hong Kong cinema Wong Kar Wai's In the Mood for Love (2000) guide the narration of the film as well. Parks indicates that in the film in which high-heeled shoes emerge as the representation of the West and modernity, slippers reflect candidness and the 'private.' After Parks' article which suggests that shoes are used as a reference to oppressive traditions and the trapped condition of the modern individual, Kate Taylor-Jones deals with Korean history over two South Korean films in terms of economic and social aspects. Jones, who states that the adoption of the liberal economic system right after the war resulted in economic inequalities and in particular the exploitation of working-class women in Korean society, contends that the psychological and sexual violence towards the female maids working in the houses of rich people who are indicated with their designer shoes in the films The Housemaid (Kim Ki-young, 1960) and The Taste of Money (Sang Soo Im, 2012) are important details which reflect the economic injustice in the country.

Following the dark narrations about the Far East, Jeff Sheible turns the direction toward America once again in his article and talks about the cooperation between two important AfroAmerican figures such as Spike Lee and Michael Jordan and Nike brand in the 1990's. In the article which touches upon the symbiotic relationship between Jordan, Spike Lee, and Nike brand, Sheible indicates how a pair of shoes is used to create a consumer fantasy through campaigns in 
which sneakers are identified with the hip hop culture and urban life and even how racism which exists in America is hidden in this fantasy world. In Hannah Hamad's article, it is expressed that the 2004 dated film I Robot (Alex Proyas) starring Will Smith, who is an equally significant AfroAmerican celebrity like Jordan is actually a part of the new era which began with the election of Barrack Obama as the American president in 2008. Hannah states that Smith, who appears in the film with his Chuck Taylor Converse All-Star sneakers, is a result of an era in which America negotiated black masculinity rather than view it as the other and that Converse sneakers commodified blackness cinematically.

Fiona Handyside draws attention to two films of Sophia Coppola, who is a fashion icon herself and the roles designer shoes played in these films. In the films Marie Antoinette (2006) and The Bling Ring (2013), it is analyzed why Coppola's young teenage characters in late capitalist societies need celebrity identities mediated in digital platforms that much. The writers deal with the stories of teenagers who define ideal womanhood as having designer shoes through the concept of 'glamour labor.' In the last article of the book, Catherine Wheatley deals with the star persona of Isabel Huppert, who is one of the most important actors of French cinema, from the perspective of her shoe preferences. Wheatley indicates that the espadrilles of the philosophy teacher named Nathalie played in Mia Hansen Love's film L'Avenir - Things to Come (2016) is both a reflection 
of the effortless but feminine French style which is Huppert symbol and expression of the style which resists the liveliness which exists in the nature of cinema.

With the help of 20 articles in Shoe Reels each more interesting and meticulous than the other, the readers do not only get a chance to go on a short journey to the history of world cinema but witness how out shoe-clothing preferences carry numerous meanings about ourselves as well. Shoes are privileged sites of gender performance and identification, shoes are sometimes a reminder of absent penis and symbol of the female genitals. While shoes at times shape the mise en scene or the narration of films, they also tell us about the social mobility of the characters in the films. While the boots of the Cossack soldiers in Eisenstein's Battleship Potemkin (1926) determine the montage rhythm in the Odessa Steps scene, Forrest Gump's (Robert Zemeckis 1994)

Nike Air Cortez sneakers help the character 'run' along the $20^{\text {th }}$ century American history. 'Shoe

Reels' is a valuable work as a book which can be read not only by 'shoe lovers' but all cinema lovers with pleasure.

Prof. Nilay Ulusoy $(\mathrm{PhD})$

Bahcesehir University Galata Campus

Kemeralti Cad. No:24 Karakoy Istanbul

$+905418300954$

nilay.ulusoy@comm.bau.edu.tr

\section{REFERENCES:}

Ezra, E. (2020). Shoe Reels: The History and Philosophy of Footwear in Film. Edinburgh: Edinburgh University Press. 